\title{
HEAVY METAL ACCUMULATION IN Ipomoea reptans AND Helianthus annuus.
}

\section{Fauziah S.H.*, Wan Siti NurHajar, W.I. and Agamuthu P.}

Institute of Biological Sciences, Faculty of Science, University of Malaya

50603 Kuala Lumpur, Malaysia

*fauziahsh@um.edu.my (corresponding author)

Received on 12th December 2011, accepted in revised form 21st March 2011.

\begin{abstract}
Heavy metals contaminations are among the most hazardous environmental pollution due to its ability to resist disintegration in the natural ecosystem. Thus, they pose risk to living organisms as they are persistent in the environment. Reports on the accumulations of heavy metal in edible plants had alarmed many parties that the general public has become more aware on the seriousness of this issue. Bioaccumulation within the food chain poses potential risks of toxicity effects. Thus, it is crucial to conduct appropriate study to analyze the pathway of the heavy metal elements as a measure to understand the behavior of the heavy metal elements. The aim of this paper is to investigate heavy metal accumulation in plant tissue, particularly the leave, stem and root. Ipomoea reptans and Helianthus аппииs were selected as the experimental plant species in the study. Spent dry cell or batteries were utilized as the source of heavy metal contamination of which batteries are commonly discarded in the municipal solid waste stream. Results indicated that the accumulation of heavy metals in the two plants were low and below the limit of European Union Standard for edible plants. However, heavy metal in alkaline batteries exposure was found to promote the growth of longer root in both plants as compared to carbon-zinc batteries and the control. Yet, the accumulation of heavy metal in the plants tissues in this study were only monitored for the period based on the maturation of the plants, longer exposure may result with different outcome, that further investigation is deemed necessary.
\end{abstract}

(Keywords: heavy metal, batteries, edible plants, bioaccumulations)

\section{INTRODUCTION}

Heavy metals are transition metals, metalloids, lanthanides and actinides that exist naturally in the ecosystem. Their existence and concentrations is highly dependent on the geological factor of the natural system and the anthropogenic activities taken place within the area $[1,2]$. Heavy metals such as $\mathrm{Hg}$, $\mathrm{Cd}, \mathrm{Pb}, \mathrm{Cr}, \mathrm{Zn}, \mathrm{Co}$ and $\mathrm{As}$ are defined as electronegative metals with density above $5 \mathrm{~g} / \mathrm{cm}^{3}$. In excess, these elements are very harmful to living tissue because of its capability to disrupt the normal metabolism and biochemical functions of an organism.

Heavy metals have similar characteristics to that of persistent organic pollutants. This is because of its ability to be bio-accumulated in the living organism. This has very significant effect to the food chain since consumption of contaminated organism by consumers of higher hierarchy will also lead to biomagnification. Organisms of the higher tropic have the higher tendency to experience severe damage to tissues and organs as the concentration of these contaminant exceeded the tolerant level of the organisms. The main factor that endangered the environment from heavy metal contamination is the fact that heavy metals are non-degradable. Thus, they persist for an extremely long time in the ecosystem until it is up-taken by certain microorganisms which have the capacity to convert some of these elements into less hazardous chemical compounds. Therefore, the limited capacity for a biological metabolism to occur where these elements are converted from toxic form to non-toxic form and vice-versa also make their existence in the environment risky [3]. The most common heavy metal contamination is soil contaminations where pollution can enter the system via various pathways namely water media, atmospheric dust particles and migrating living organisms.

Heavy metal contamination in soil can also lead to contamination to plant tissues. This is particularly due to the absorption activities of the plants. As plants make the base of the tropic level in an ecosystem, the contamination also affect the organisms of higher hierarchy. Thus, soil contamination is a serious issue of concern due to its effect to plants at the lower hierarchy and human at the higher hierarchy of the food chain [3]. $\mathrm{Hg}$ contamination in 1975 in Iraq was reported to kill 5000-50,000 people due to the consumption of wheat 
cultivated on a contaminated soil, while in Japan Minamata disease depicted the seriousness of the bioaccumulation of heavy metal namely $\mathrm{Hg}$, as 111 people were dead and thousands more suffered chronic diseases $[4,5]$. Similar events were also recorded in Pakistan, Guatemala, Amazonia, Thailand and the United States of America. Thus, heavy metal contamination is a serious matter which should not be considered lightly. Even though heavy metal elements are hazardous when accumulated in the plant tissues, these elements are crucial and necessary for plant growth including $\mathrm{Mg}, \mathrm{K}, \mathrm{Cr}$, and $\mathrm{Mn}$.

Among the common non-metallic elements essential for plants growth are $\mathrm{C}, \mathrm{H}, \mathrm{O}, \mathrm{N}, \mathrm{P}$ and $\mathrm{S}$. These elements are the macronutrient crucial to form protein and protoplasm. Additionally, $\mathrm{Ca}, \mathrm{Mg}, \mathrm{K}, \mathrm{Fe}$, $\mathrm{Mn}, \mathrm{Mo}, \mathrm{Cu}, \mathrm{B}, \mathrm{Zn}, \mathrm{Na}$ and $\mathrm{Cl}$ are needed in trace quantity as these elements are the micronutrients for plants. Some of the heavy metals are also needed in trace quantity that they are actively transported into the plant tissues.

Different plants have different level of dependency on the supply of micronutrient. Insufficient micronutrients will hamper growth in certain plants. This is so because many micronutrients are important elements in enzyme construction while others play role in the metabolic pathways. Aside from that, these elements normally are the limiting factors for plant growth. In exceeded concentration these elements will be stored within the plant system namely living tissue of leaves, root or stem, as autotrophs lack the means to flush waste out of their system. Yet, this accumulation of micronutrient and other heavy metals in plants cause no detrimental effects to the plant system, unlike that of higher tropic organisms. Thus this make plant invisible to detrimental effects of the heavy metal contamination that plants are able to grow at any soil media appropriate to their tolerant range.

Soil contamination can also resulted from the indiscriminate disposal of municipal solid waste (MSW) which contain hazardous component. Thus, improper waste disposal particularly open dumping activities can lead to contamination of toxic compound to the surface and groundwater system, and to surface soil [1]. Toxic components originated from various sources namely industrial waste and household hazardous waste. In Malaysia, approximately $2 \%$ of the total MSW generated is household hazardous waste which includes pesticide cans and batteries [6].
Used batteries have no market values that they will remain in the landfill without any possibility of being extracted for recycling purpose. Therefore, once the leaching process started, heavy metal such as $\mathrm{Pb}, \mathrm{Zn}$, $\mathrm{Cd}, \mathrm{Hg}, \mathrm{Ni}$ and $\mathrm{Li}$ can contaminate the surrounding area, and these components are highly toxic to living organisms.

This study is aimed to investigate the bioaccumulation of heavy metal in plants. Therefore, for the purpose of the study Helianthus annuus and Ipomoea reptans were selected due to their potential as edible and hyperaccumulative plants. Source of heavy metal is from the exposure of used batteries.

\section{MATERIALS AND METHODS}

\section{Experimental Plants}

Helianthus annuus belongs to the Asteraceae family of the Asterales order. This native American plant is normally found in North America, Canada and Mexico at $1900 \mathrm{~m}$ above sea level. Yet, it is widely cultivated in many parts of the world for edible oil extraction.

Ipomoea reptans belongs the Convolvulaceae family of the Solanales order. This plant grows well in tropical climate and easily found on soggy soil or in the aquatic environment. It is also very common in landfill area where surrounding soil has direct contact with landfill leachate, thus provide extremely high supply of nutrient. This plant is also known as water spinach and edible as vegetable.

\section{Heavy metal exposure}

Commercial seedlings were used for this study. Nursery for the seedlings consist of commercial soil, free from heavy metals. The seedlings of both plants were allowed to grow to $10 \mathrm{~cm}$ high for Helianthus annuus and $7 \mathrm{~cm}$ high for Ipomoea reptans. Three treatments namely E1 alkaline batteries exposure, E2 $\mathrm{C}-\mathrm{Zn}$ batteries exposure and E3 control (no heavy metal exposure) were set-up with three plants each in polybags with approximately $5 \mathrm{~kg}$ of soil.

Spent batteries were placed $5 \mathrm{~cm}$ below the soil surface. Each treatment with five replicates (totaling 15 plants for each treatment) were placed under planting nets to reduce rain intrusion. Irrigation is conducted daily where $10 \mathrm{ml}$ of distilled water were watered into each polybags that contained the plants. Height and number of leaves were recorded throughout the experiment and the plants were 
removed from the contaminated soil after five weeks. The analysis of the plants were conducted where part of the plants namely leaf, stem and root were aciddigested and analyzed for its heavy metal content with ICP-AES.

\section{RESULTS AND DISCUSSIONS}

The exposure to different types of batteries resulted with different concentration of bioaccumulation by the experimental unit. The bioaccumulation of heavy metals such as $\mathrm{Cd}, \mathrm{Al}, \mathrm{Mn}, \mathrm{Cu}, \mathrm{Zn}$, and $\mathrm{Fe}$ in Helianthus annuus and Ipomoea reptans were below the European Union Standard [8] to cause toxicity to living tissues. However, prolonged exposure may give result differently. Consecutive sections discuss the detail results of bioaccumulation in the two types of plants.

\section{Bioaccumulation in Helianthus annuus}

Growth rate of Helianthus annuus in media exposed to alkaline batteries (E1) was the highest compared to C-Zn batteries (E2) and the control (E3) (Figure 1). This rapid growth gave a linear regressions $\mathrm{y}=5.5 \mathrm{x}+$ $5.1\left(R^{2}=0.9658\right)$ for $E 1$ followed by $E 2$, the $C-Z n$ batteries with linear regression $\mathrm{y}=4.9 \mathrm{x}+7.1\left(\mathrm{R}^{2}=\right.$ 0.9889). Batteries exposed media promoted a more rapid growth for Helianthus annuus than the control due to the presence of elements necessary for plant growth such as $\mathrm{Zn}$ which is lacking in the control media. Thus, the plants grow better in the exposed media than the control. Among the two exposed media, E1 promoted better growth. This is probably due to the abundant of additional elements such as $\mathrm{Mn}, \mathrm{Cd}$, and $\mathrm{Ni}$ which are needed in trace amount for plant growth [9].

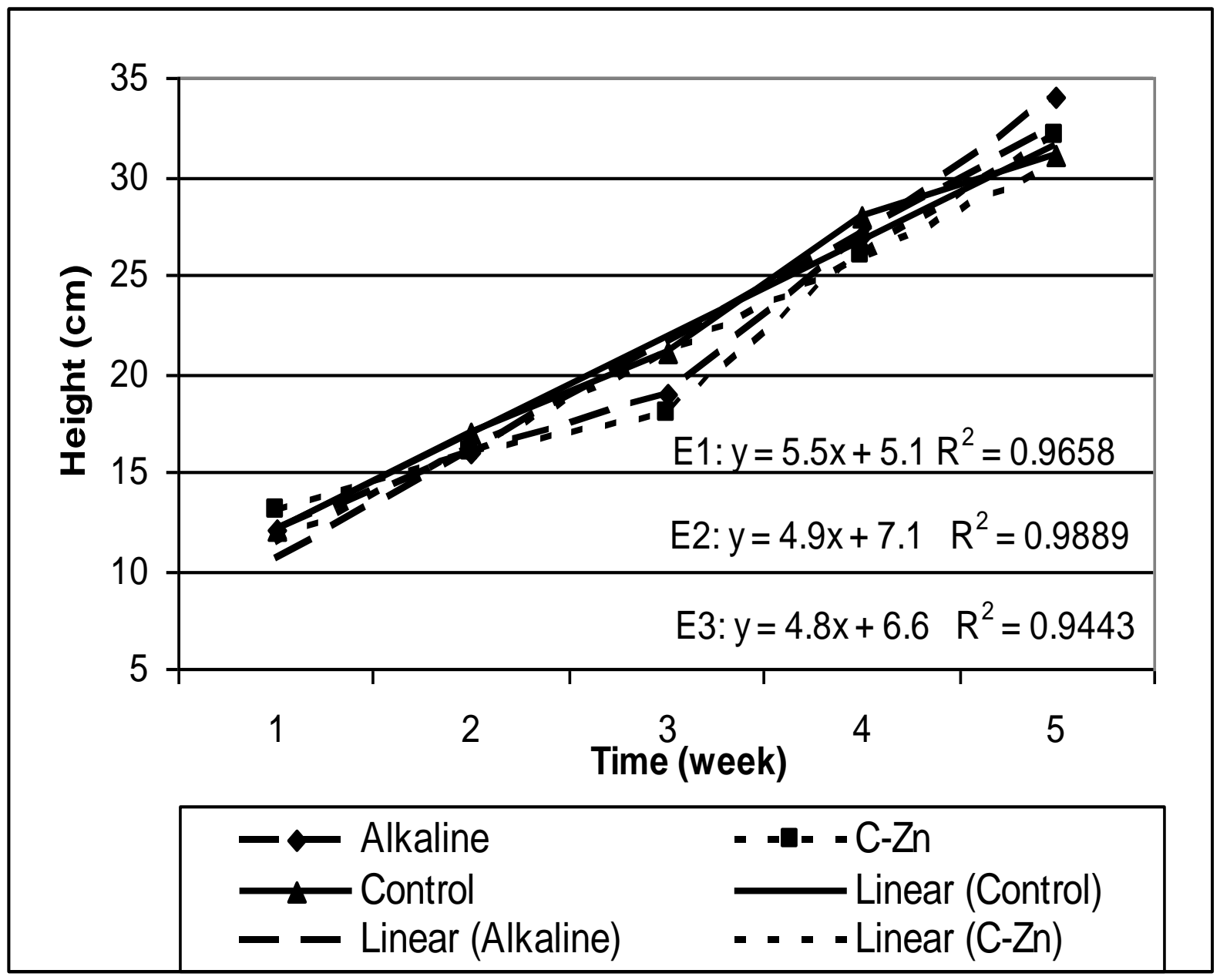

Figure 1. Height of Helianthus annuus over time

As for the number of leaves in Helianthus annuus, E1 treatment indicated the highest number followed by
E2 and E3. The linear regression obtained from E1 data is $\mathrm{y}=1.16 \mathrm{x}+5.18\left(\mathrm{R}^{2}=0.9234\right)$ indicating that 
number of leaves will increase over time. The results is so, possibly due to the presence of the additional metal elements ( $\mathrm{Mn}, \mathrm{Cd}$, and $\mathrm{Ni}$ ) in $\mathrm{E} 1$ media compared to E2 with just Zn and E3 which lack of any. The presence of trace element in the growing media will definitely promote rapid production of leaves as it also allowed active photosynthesis to occur [9]. Additionally, E2 media also contain K which is an essential nutrient for plants necessary for osmotic balance and ion exchange process in plant tissues. The exposure has probably resulted with increase in photosynthesis and decrease in respiration [3].

The analysis on stem, leaves, and root indicated that different parts of plant have the tendency to accumulate different types of metal elements. The concentrations of the accumulation are also found to differ among the different types of metal. Heavy metal with the highest concentration up-taken by Helianthus annuus was $\mathrm{Zn}$, ranging from $0.35-1.1 \mathrm{mg} / \mathrm{kg}$. This probably resulting from the presence of $\mathrm{Zn}$ in both $\mathrm{E} 1$ and $\mathrm{E} 2$ since $\mathrm{Zn}$ made the essential component in batteries i.e. as the anode, as compared to other metals such as $\mathrm{Cd}, \mathrm{Al}, \mathrm{Mn}, \mathrm{Cu}$ and $\mathrm{Fe}$. Figure 2 illustrates the concentration of heavy metals within the plant tissues namely of E1, E2 and E3 of Helianthus annuиs.

For E1 and E2, accumulation of Zn was the highest in the root and stem. It was approximately $0.9 \mathrm{mg} / \mathrm{kg}$ in the stem of Helianthus annuus. As for accumulation of $\mathrm{Fe}$, the concentration was very low (approximately $0.01 \mathrm{mg} / \mathrm{kg}$ ) in the stem, leaves and the root tissues of the plant. This probably is due to the interference of uptake of other metal (such as Fe) as a result of the abundance of $\mathrm{Zn}$ within the living tissue. The ability of plants to absorb other essential metals has been reported to be disrupted during the presence of $\mathrm{Zn}$ in abundance [10]. However, the bioaccumulation of $\mathrm{Mn}$ was approximately $0.07-0.2 \mathrm{mg} / \mathrm{kg}$. For E1, Mn was distributed throughout the plants at a concentration of $0.2 \mathrm{mg} / \mathrm{kg}$ while for E2, it mainly accumulated in the leaves. It is due to the fact that $\mathrm{Mn}$ is crucial for enzyme activation such as for desulfidrase, deoxyribonuclease and phosphatase, which are actively involved in the metabolism within the leaf tissues.

The accumulation of heavy metal such as $\mathrm{Cd}$ and $\mathrm{Cu}$ in Helianthus annuus were approximately 0.04-0.05 $\mathrm{mg} / \mathrm{kg}$ and $0.03-0.08 \mathrm{mg} / \mathrm{kg}$, respectively. This may indicate that only low concentration of these heavy metals leached from the batteries that the bioaccumulation within the living tissues of exposed media was not significantly different from the control. This is not agreeable to the findings of January et al [9], which implied that Helianthus annuus being a hyperaccumulative plant for $\mathrm{Cr}, \mathrm{Cu}, \mathrm{Mn}, \mathrm{Pb}$ and $\mathrm{Zn}$ accumulation. As for the concentration of $\mathrm{Al}$, it was found the highest in the root of E3, ranged from 0.12 $\mathrm{mg} / \mathrm{kg}$ to $0.2 \mathrm{mg} / \mathrm{kg}$. The accumulation of $\mathrm{Al}$ is high in E1 compared to E2 and E3 because of the fact that Al also contributed to the component of alkaline batteries. Thus, $\mathrm{Al}$ is higher in E3 as compared to other media in the experiment.

\section{Bioaccumulation in Ipomoea reptans}

Almost similar responses were observed from the growth of Ipomoea reptans, as that of Helianthus annuus. The exposure of heavy metals from batteries to Ipomoea reptans indicated a rapid increase in number of leaves in E2. This generally could be contributed to the difference in the abundance of $\mathrm{Zn}$ in the experimental set-ups. E2 has higher $\mathrm{Zn}$ supply than $\mathrm{E} 1$ with the presence of $\mathrm{ZnCl}_{2}$ in the batteries. This enabled the rapid generation of leaves in E2. However, abundance of other macro and micronutrients in $\mathrm{E} 1$ promote more rapid increase in plant height than that of E2 and control. The most rapid increase in plant height was observed in E1 plants with a linear regression $\left(\mathrm{R}^{2}=0.9636\right)$ (Figure $3)$.

Similar to that of Helianthus annuus, the highest metal accumulated in Ipomoea reptans was $\mathrm{Zn}$. The high concentrations were found in the stem, leaves and root tissue ranging from $0.4 \mathrm{mg} / \mathrm{kg}$ to $1.16 \mathrm{mg} / \mathrm{kg}$. For E1, accumulation of $\mathrm{Zn}$ was highest in the leaves and root, indicating the importance of $\mathrm{Zn}$ in the metabolic reaction of the plants. On the other hand, for E2, $\mathrm{Zn}$ was mainly accumulated in stem and leaf tissues.

This can be explained with the fact that abundance of $\mathrm{Zn}$ inhibits the uptake of other essential metal within a plant system [10]. As a result, the accumulation of $\mathrm{Fe}$ in the plant tissues was the lowest as compared to that of other metals. No significant difference was found in the three experimental media for the accumulation of $\mathrm{Cd}$. For all experiments, approximately $0.05 \mathrm{mg} / \mathrm{kg}$ of $\mathrm{Cd}$ was found each in the stem, leaf and root of the plants. This probably indicated that there is no significant leaching of $\mathrm{Cd}$ from the batteries into the experimental media. 

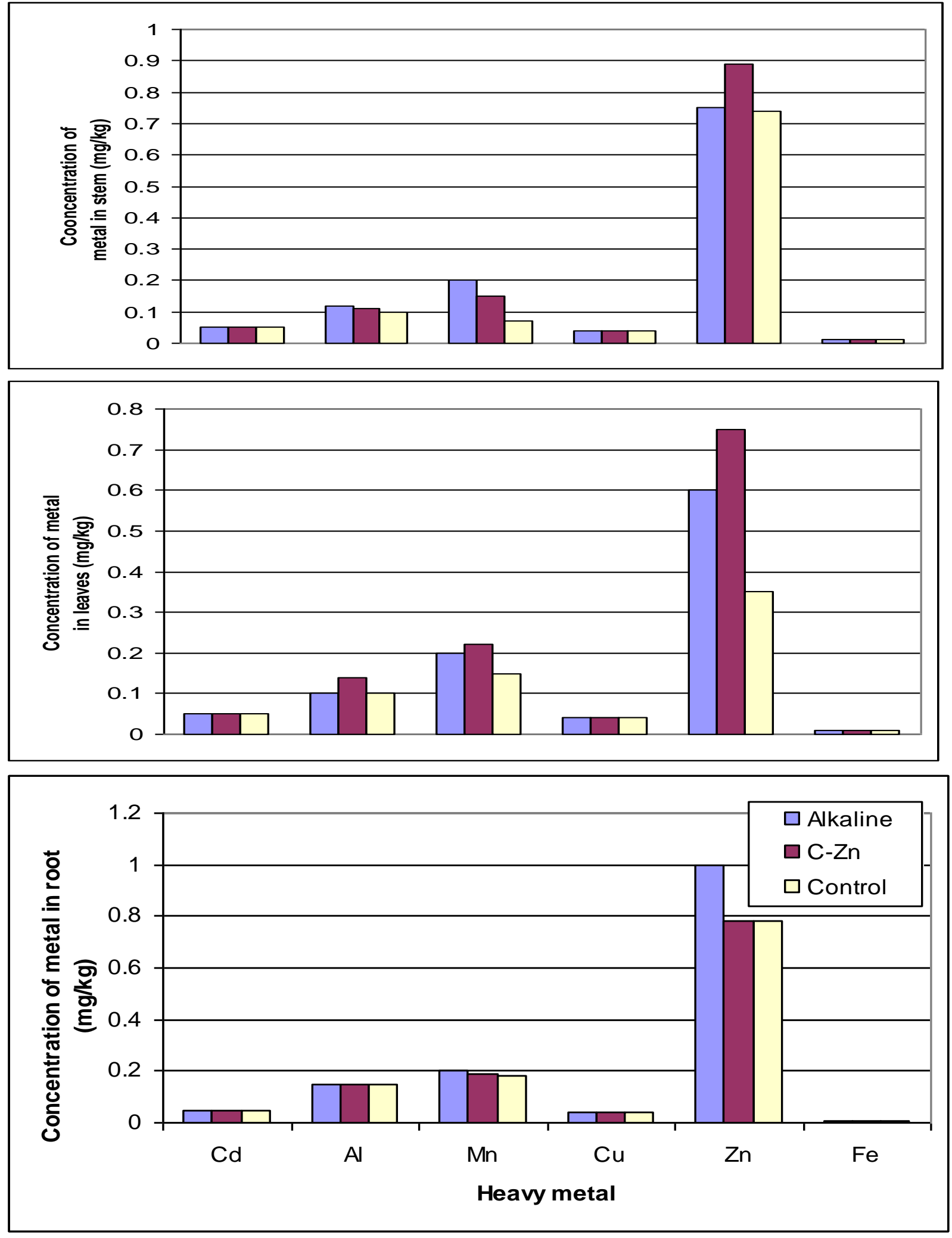

Figure 2. Concentration of metal in Helianthus annuus. (this should go up) 


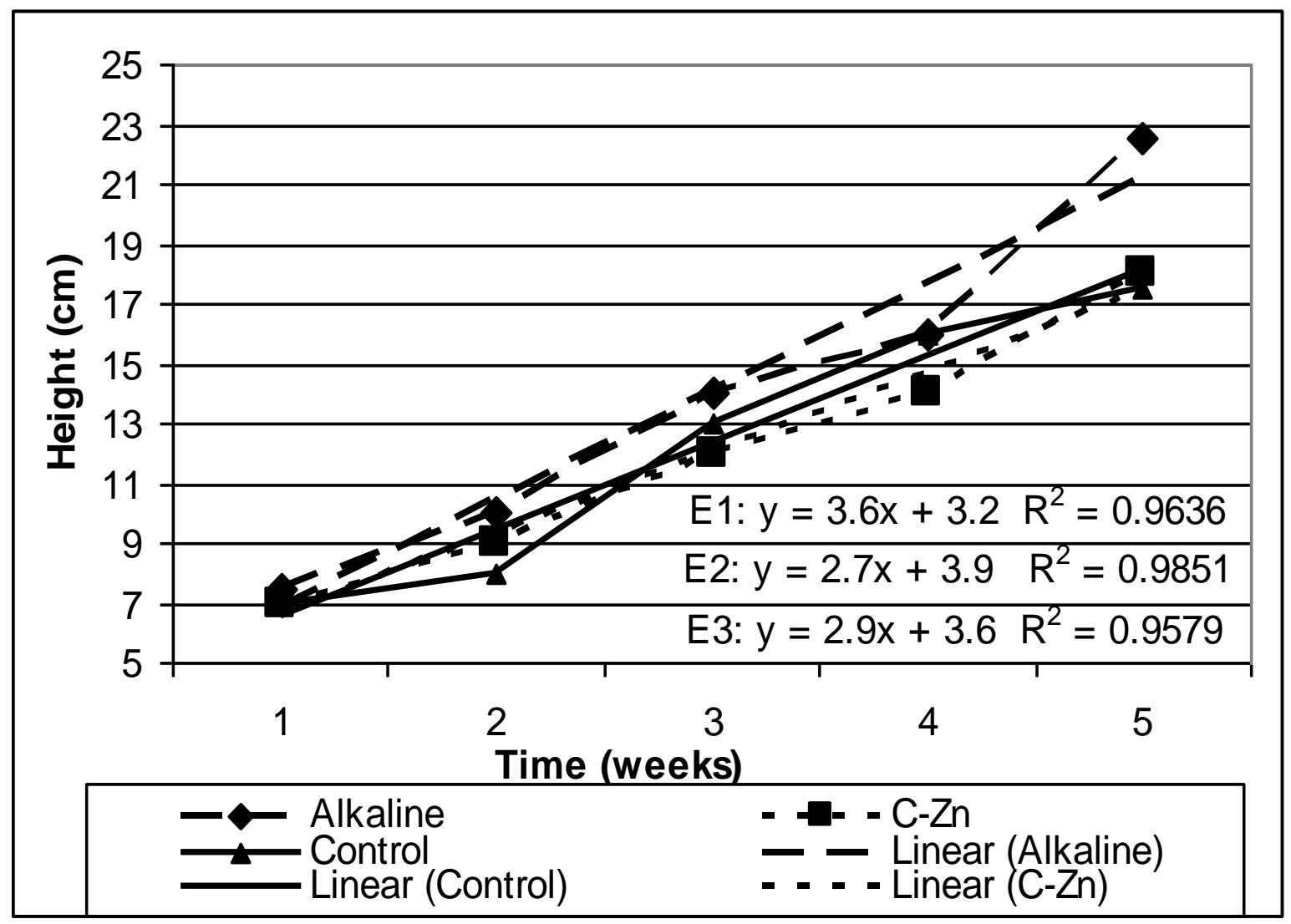

Figure 3. Height of Ipomoea reptans over time

Thus, the concentration of $\mathrm{Cd}$ in batteries-exposed media is no different to the control media. Ultimately, no significant different in the uptake of $\mathrm{Cd}$ can be obtained from the study. Figure 4 depicts the accumulation of selected metals in stem, leaves and root of Ipomoea reptans.

Yet, the accumulation of $\mathrm{Al}$ was found to be significantly different in E1 and E2 as compared to that of E3. The highest $\mathrm{Al}$ concentration was in the root system followed by the stem tissue of the E1, while for E2, it was in the root system.

\section{Comparison in both plants}

The accumulation of $\mathrm{Al}$ in the leaves of Ipomoea reptans was significantly higher than that of Helianthus annuus. Thus, this indicated that in comparison, Ipomoea reptans is a more hyperaccumulative plant than Helianthus annuus for the accumulation of Al. Hyperaccumulative plants was reported to be more adaptable to toxic environment than the non-hyperaccumulative $[11,12]$. Therefore, $\mathrm{Al}$ was found higher in Ipomoea reptans than in Helianthus annuus as $\mathrm{Al}$ has been reported to be commonly accumulated in the root rather than other parts of the plants [13]. In addition, Al toxicity limit the productivity of plants whereby inhibit growth to the less tolerant plants [13, 14].

Results indicated that exposure to alkaline batteries (E1 treatment) promoted root elongation in both plant species where E1 treatment showed plants with the longest root length as compared to E2 and control (Figure 5). This probably is due to fact that the availability of metal leached out from alkaline batteries is higher and faster that it is transported into the deeper part of the soil medium, thus promote the root to grow longer in order to absorb it. Root has been proven to play a very significant role in absorption of metal element in addition to nutrient supplied into a plant system [15]. The length of the root in both plant species exposed to alkaline batteries were significantly higher than the other two experiments $(\rho=0.05)$. Ipomoea reptans displayed longer root length as compared to that of Helianthus annuus, which can be translated that the former is a better hyperaccumulator than the latter. 

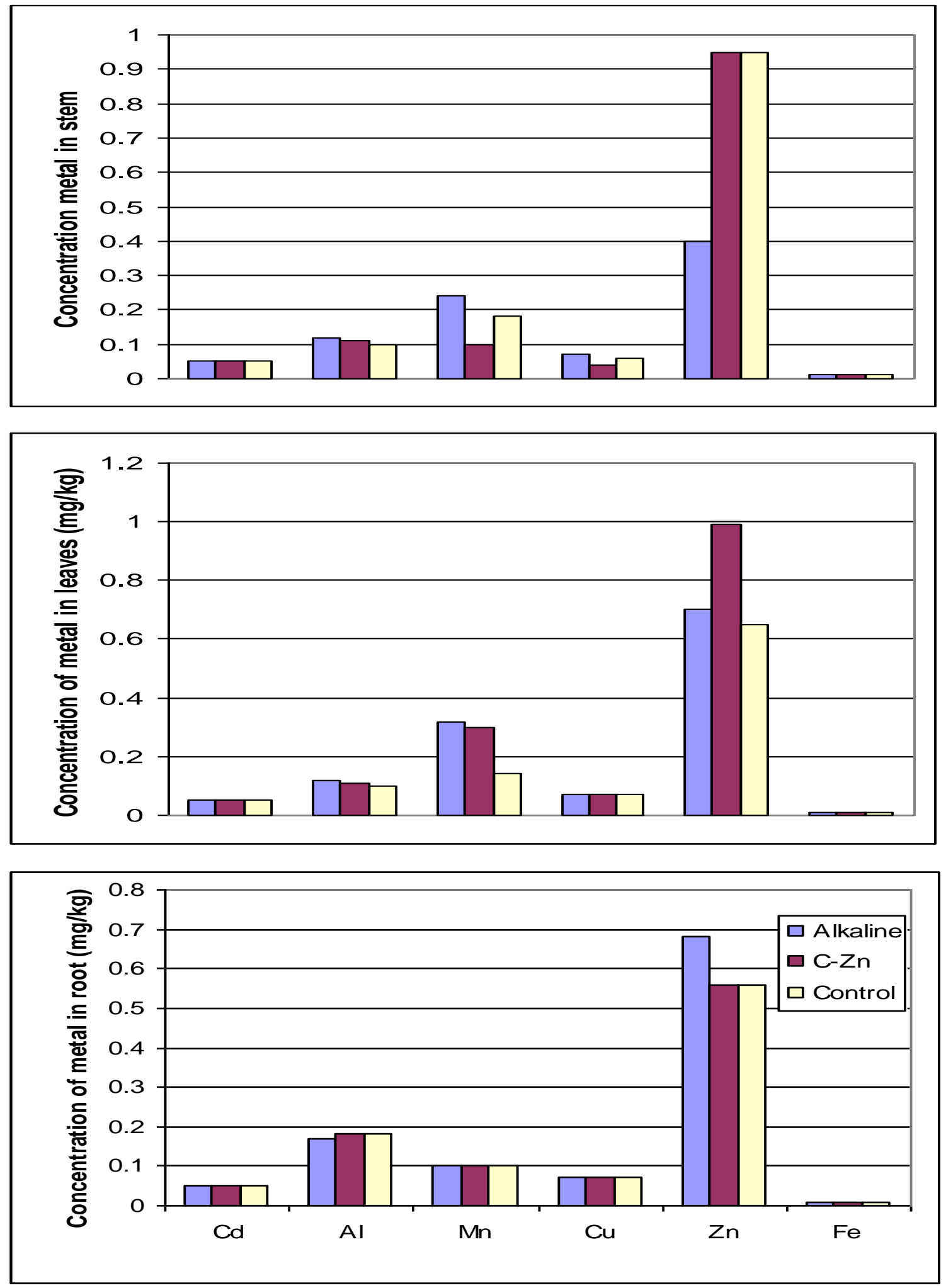

Figure 4. Concentration of metal in Ipomoea reptans. (this should go up as well) 


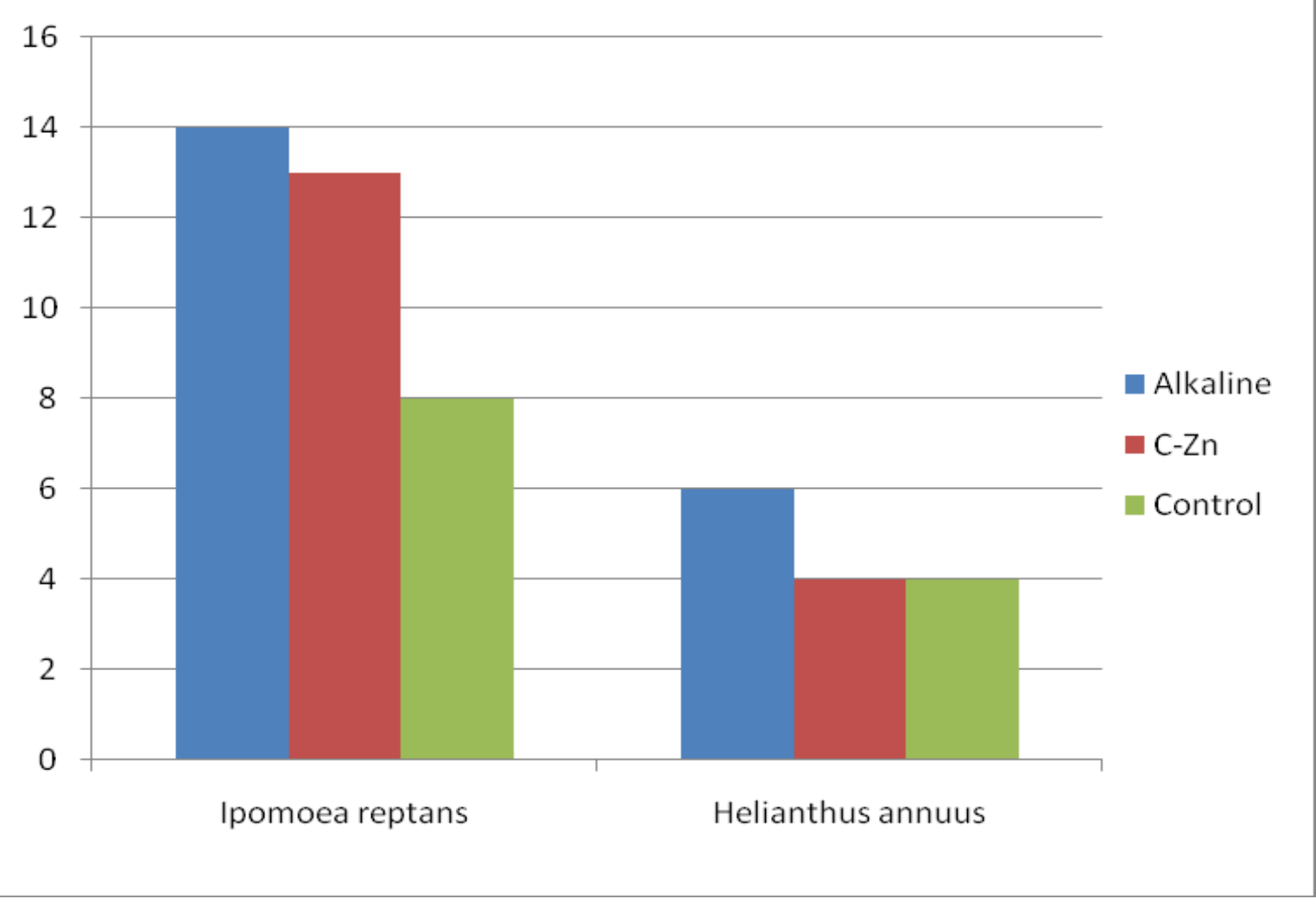

Figure 5. Average length of roots in Helianthus annuus and Ipomoea reptans.

\section{CONCLUSIONS}

Results indicated that the bioaccumulation of heavy metal in plants varied with the elements and storage tissue types. When exposed to batteries, Ipomoea reptans accumulated the largest quantity of metal in the leaves while Helianthus annuus stored it mainly in the root and stem. However the accumulated heavy metals are below the concentration to pose any risk to human consumption. This indicated that the exposure of batteries does not pose serious issues in soil over a short period of time. However, further studies need to be conducted to investigate the risk to human consumption.

\section{REFERENCES}

1. Agamuthu, P., Mohd Jamil M., Fauziah S.H. and Noorazamimah Aiza, A. (2007) Health and Environmental Impacts of reclamation of Exmining Land- A Malaysian Case Study. Proceedings of the 2007 International Symposium on Environmental Science and Technology, (ISEST) China. pp. 42-47. June 2007.
2. Nadal, M., Schuhmacher, M. and Domingo, J.L. (2004) Metal pollution of soils and vegetation in an area with petrochemical industry. Science of the Total Environment, 321: 59-69.

3. Kassasi, A., Rakimbei, P., Karagiannidis, A., Zabaniotou, A., Tsiouvaras, K., Nastis A. and Tzafeiropoulou, K. (2008) Soil contamination by heavy metals: Measurements from a closed unlines landfill. Bioresource Technology, 99:8578-8584.

4. Fadil, O. (1996) Permasalahan alam sekitar Kuala Lumpur. (In Bahasa Malaysia) Dewan Bahasa dan Pustaka, Kuala Lumpur. pp 24. (1996).

5. Mohd Zulkarnain, M.K. (2007) Kajian kandungan logam berat dalam sedimen di tasik berdekatan Arked Kolej 16. (In Bahasa Malaysia) Thesis. University Technology of Malaysia, Johor.

6. Fauziah, S.H. and Agamuthu, P. (2008) Household hazardous waste components in Malaysian municipal solid wastes: The current scenario. Proceedings of the 1 st International Hazardous Wastes Conference, Chania-Crete, Greece. 1- 3 October 2008. 
7. Agamuthu, P., Fauziah S.H. and Khidzir, K.M. (2009) The evolution of solid waste management in Malaysia: Impacts and implications of the Solid Waste Bill, 2007. Journal of Material Cycles and Waste Management, 11(2): 96-103.

8. EU, Commission Regulation (EC) 466/2001. (2001). Setting maximum levels for certain contaminants in foodstuffs. Official Journal of the European Communities, pp. 77.

9. January, M.C., Cutright, T.J., Keulen, H.V. and Wei, R. (2008) Hydroponic phytoremediation of $\mathrm{Cd}, \mathrm{Cr}, \mathrm{Ni}, \mathrm{As}$, and $\mathrm{Fe}$ : Can Helianthus annuиs hyperaccumulate multiple heavy metals? Chemosphere, 70(3): 531-537.

10. Muchuweti, M., Birkett, J.W., Chinyanga, E., Zvauya, R., Scrimshaw, M.D. and Lester, J.N. (2006) Heavy metal content of vegetables irrigated with mixtures of wastewater and sewage sludge in Zimbabwe: Implications for human health. Agriculture, Ecosystems \& Environment, 112 (1): 41-48.

11. Liu, J. Zhou, Q., Sun, T., Ma, L.Q. and Wang, S. (2008) Growth responses of three ornamental plants to $\mathrm{Cd}$ and $\mathrm{Cd}-\mathrm{Pb}$ stress and their metal accumulation characteristics. Journal of Hazardous Materials, 151(1): 261267.

12. Zhang, X., Xia, H., Li, Z., Zhuang, P. and Gao, B. (2011) Identification of a new potential Cdhyperaccumulator Solanum photeinocarpum by soil seed bank-metal concentration gradient method Journal of Hazardous Materials, 189(12): 414-419.

13. Ma, J. F., Ryan, P.R. and Delhaize, E. (2001) Aluminium tolerance in plants and the complexing role of organic acids. Trends in Plant Science, 6(6): 273-278.

14. Guo, T.R., Zhang, G.P. and Zhang, Y.H. (2007) Physiological changes in barley plants under combined toxicity of aluminum, copper and cadmium. Colloids and Surfaces B: Biointerfaces, 57(2): 182-188.

15. Madrid, F., Diaz-Barrientos, E. and Madrid, L. (2008) Availability and bio-accessibility of metals in clay fraction of urban soils of Sevilla. Environmental Pollution, 156: 605-610. 